\title{
A Comparison of Methods Used to Estimate the Maturity and Release of Ascospores of Venturia inaequalis
}

\author{
David M. Gadoury and Robert C. Seem, Department of Plant Pathology, Cornell University, New York State Agri- \\ cultural Experiment Station, Geneva 14456; William E. MacHardy, Department of Plant Biology, University of \\ New Hampshire, Durham 03824; Wayne F. Wilcox and David A. Rosenberger, Department of Plant Pathology, \\ Cornell University, New York State Agricultural Experiment Station, Geneva 14456; and Arne Stensvand, Depart- \\ ment of Plant Pathology, Plant Protection Centre, The Norwegian Crop Research Institute, N-1432 Ås, Norway
}

\begin{abstract}
Gadoury, D. M., Seem, R. C., MacHardy, W. E., Wilcox, W. F., Rosenberger, D. A., and Stensvand, A. 2004. A comparison of methods used to estimate the maturity and release of ascospores of Venturia inaequalis. Plant Dis. 88:869-874.

Maturation and release of ascospores of Venturia inaequalis were assessed at Geneva and Highland, NY, and at Durham, NH, by microscopic examination of crushed pseudothecia excised from infected apple leaves that were collected weekly from orchards (squash mounts) in 14 siteyear combinations. Airborne ascospore dose was monitored at each location in each year of the study by volumetric spore traps. Additional laboratory assessments were made at Geneva to quantify release from infected leaf segments upon wetting (discharge tests). Finally, ascospore maturity was estimated for each location using a degree-day model developed in an earlier study. Ascospore maturation and release determined by squash mounts and discharge tests lagged significantly behind cumulative ascospore release as measured by volumetric spore traps in the field. The mean date of $98 \%$ ascospore discharge as determined by squash mounts or discharge tests occurred from 23 to 28 days after the mean date on which $98 \%$ cumulative ascospore release had been detected by volumetric traps. In contrast, cumulative ascospore maturity estimated by the degree-day model was highly correlated $\left(r^{2}=0.82\right)$ with observed cumulative ascospore release as monitored by the volumetric traps. Although large differences between predicted maturity and observed discharge were common during the exponential phase of ascospore development, the date of $98 \%$ cumulative ascospore maturity predicted by the model was generally within 1 to 9 calendar days of the date of $98 \%$ cumulative ascospore recovery in the volumetric traps. Cumulative ascospore discharge as monitored by the volumetric traps always exceeded $98 \%$ at 600 degree days $\left(\right.$ base $=0^{\circ} \mathrm{C}$ ) after green tip. Estimating the relative quantity of primary inoculum indirectly by means of a degree-day model was more closely aligned with observed ascospore release, as measured by volumetric traps, than actual assessments of ascospore maturity and discharge obtained through squash mounts and discharge tests. The degreeday model, therefore, may be a more accurate predictor of ascospore depletion than squash mounts or discharged tests, and has the added advantage that it can be widely applied to generate site-specific estimates of ascospore maturity for any location where daily temperature data are available.
\end{abstract}

Ascospores of Venturia inaequalis (Cooke) G. Wint. constitute the principal source of primary inoculum for epidemics of apple scab $(29,30)$. The loculostromata form in infected leaves shortly after leaf fall, develop into pseudothecia in late winter and early spring, and release ascospores during rain beginning shortly after bud break of apple. The duration of the period of ascospore discharge has been variously reported as extending from 6 to 12 weeks $(4,5,24,30,41,46-49)$. Both the relative and absolute quantity of ascospores discharged during various portions of this period af-

Corresponding author: D. M. Gadoury

E-mail: dmg4@ cornell.edu

Accepted for publication 12 April 2004.

Publication no. D-2004-0607-03R

(C) 2004 The American Phytopathological Society fect the scheduling of fungicides for control of apple scab.

Absolute measures of primary inoculum include estimates of the density of the pathogen population, either on the orchard floor or in the air. Gadoury and MacHardy (14) defined potential ascospore dose (PAD) as the total production of ascospores per $\mathrm{m}^{2}$ of orchard floor per season. In subsequent studies, Gadoury et al. (15), MacHardy et al. (34), and Wilcox et al. (52) successfully delayed the onset of fungicide spray programs to coincide with the anticipated delay of an epidemic in orchards where PAD was low. Spore traps have been used to measure airborne ascospore dose of $V$. inaequalis in several studies $(1,3,18,25,32,39,45,46)$. However, the expense and labor-intensive nature of this work, coupled with a general lack of information relating airborne dose to disease development, has often limited the application of such data in disease management.
Relative measures of inoculum maturity and release have long been employed in advisory programs for management of apple scab $(12,23,48)$. Microscopic examination of crushed pseudothecia of $V$. inaequalis (squash mounts) are used to determine the relative proportions of immature, mature, and discharged asci at various times during the growing season $(11,23,48)$. A number of modifications to this basic method have been proposed $(11,16,17)$. However, no studies have heretofore addressed the accuracy of these various assessments in reflecting the airborne ascospore dose. The discharge of ascospores from leaf samples in wind tunnels $(20,22)$ or over water-filled petri plates (48), and their subsequent enumeration by microscopy or enzyme-linked immunosorbent assay (ELISA), has also been used to monitor the seasonal availability of inoculum. While useful to detect the qualitative presence of ascospores in leaf samples, the quantitative relationship between these counts and the airborne dose in the field has not been described. A report by Aylor (1) indicated that repeated harvests of ascospores from field-stored leaves fail to account for attrition in the ascospore population due to leaf decomposition, resulting in overestimation of the potential airborne ascospore supply in late spring.

Gadoury and MacHardy (12) described a simple model to estimate the maturity of ascospores of $V$. inaequalis based upon degree-day accumulation. The model has been used in conjunction with forecasted degree-day accumulation to forecast ascospore maturity up to 1 month in advance (31). Data on rain events late in the process of ascospore maturation can be used with the model to estimate the date of depletion of the ascospore supply, an event which often signals a reduction of fungicide use against apple scab $(12,19,31)$. Of all the commonly used methods, only the degreeday model provides a confidence interval for the estimated maturity. Although estimates generated by squash mounts have been analyzed for the purpose of designing better sampling plans (16), the variance associated with an estimate obtained through squash mounts or discharge tests is rarely reported. The degree-day model has been evaluated in several studies $(12,39,40,45)$. 
There are, therefore, at least three distinct methods used to monitor the maturation and discharge of ascospores of $V$. inaequalis: squash mounts, discharge tests, and a degree-day model. Each method can be used to construct a cumulative distribution of relative inoculum dose to delimit the season of ascospore release, identify periods of relatively high and low risk for primary infection, and thereby affect the timing, rate, and frequency of fungicide applications. However, estimates obtained by squash mounts often deviate from results obtained by discharge tests, and both may deviate from estimates generated by the degree-day model. The ultimate standard of accuracy for the various methods should be how closely each reflects the relative quantity of inoculum to which apple trees are exposed, i.e., airborne ascospore dose. However, such comparative data are lacking. Therefore, our objective was to evaluate each method against measurements of airborne ascospore dose determined with volumetric spore traps.

\section{MATERIALS AND METHODS}

Volumetric spore traps. A Burkard volumetric spore trap (Burkard Manufacturing Co. Ltd., Rickmansworth, Hertford-

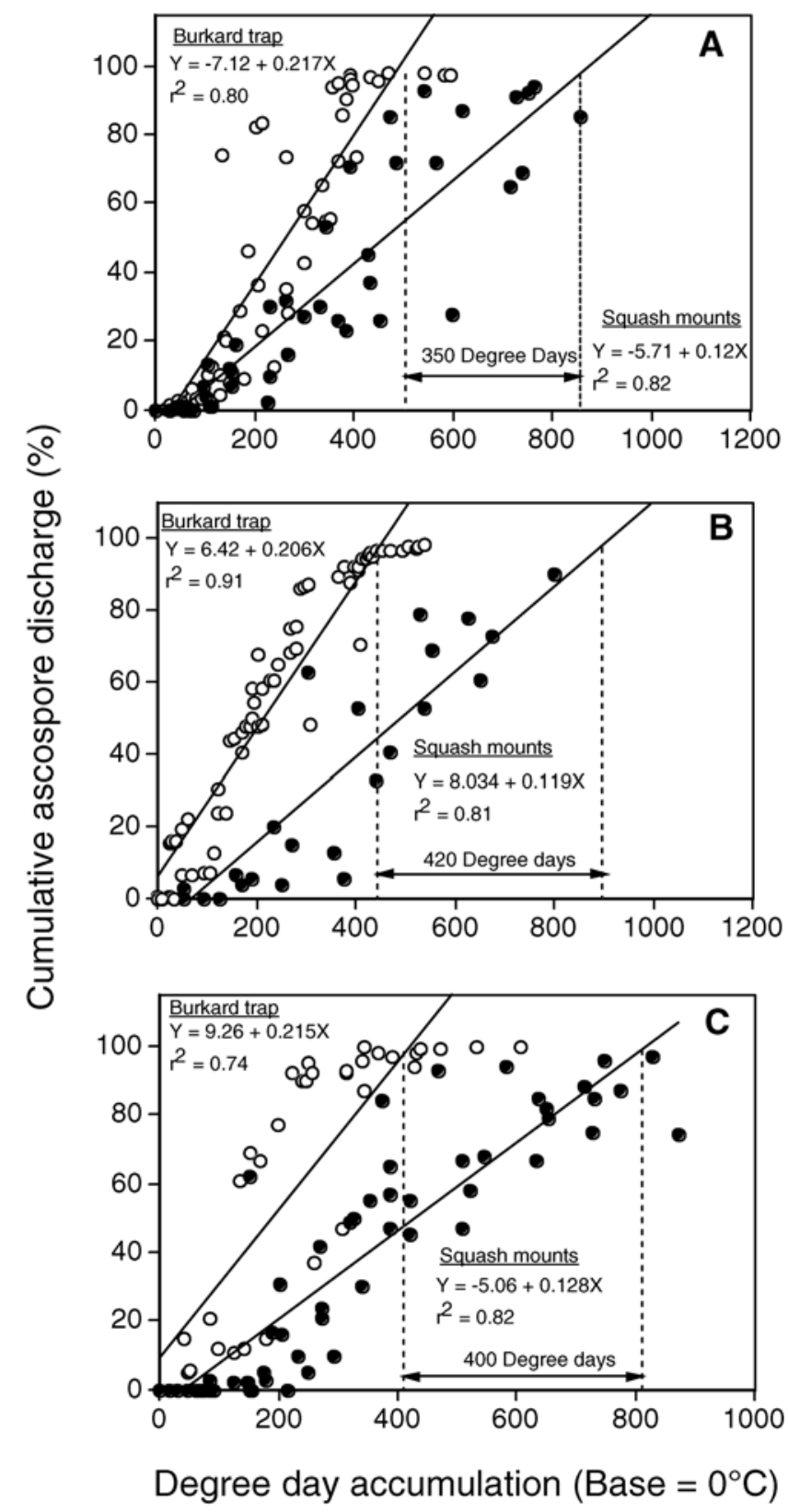

Fig. 1. Cumulative percentage of ascospores of Venturia inaequalis trapped by a Burkard volumetric spore sampler $(\mathrm{O})$ compared with the cumulative percentage of empty asci in crushed pseudothecia (•). A, Highland, NY, 1986 to 1990; B, Geneva, NY, 1992 to 1994; and C, Durham, NH, 1986 to 1990. Degree-day accumulation (base $=0^{\circ} \mathrm{C}$ ) was calculated from the date of green tip of the apple cultivar McIntosh. Occurrence of $98 \%$ cumulative ascospore release generated by linear regression models fit to the two data sets differed by 350 to 420 degree days, which at a mean daily temperature of $15^{\circ} \mathrm{C}$ is equivalent to 23 to 28 days.

shire, England) was operated for the following periods at each of the following sites: from 1986 to 1990 at the Mast Road Research Orchard in Durham, NH; from 1992 to 1994 at the New York State Agricultural Experiment Station in Geneva, NY; and from 1985 to 1990 at the Hudson Valley Fruit Research Laboratory in Highland, NY. At each site, the trap was situated within the rows of an orchard containing several trees of the cultivar McIntosh that were unsprayed the previous season, and were severely diseased. The leaf litter beneath these trees provided ample airborne inoculum for collection during rain events beginning at bud break and continuing until the airborne ascospore supply was depleted. Traps were powered by $12-\mathrm{V}$ deep-cycle marine batteries that were replaced and recharged every 5 to 7 days.

Recording tapes from the traps were removed weekly, mounted on glass slides, and examined microscopically at 2-mm (1h) intervals for ascospores of $V$. inaequalis, as described by Gadoury and MacHardy (13). Cumulative percentages of ascospores trapped daily were calculated from the summation of the hourly counts.

Squash mounts. Ten overwintered infected leaves were collected at 5- to 10-day intervals at each trapping site during the period that the volumetric traps were operated. Twenty pseudothecia (two per leaf) were removed from these leaves, crushed on glass slides, examined microscopically, and the percentage of immature, mature, and discharged asci were calculated as described by Gadoury and MacHardy (11).

Discharge tests. At Geneva, four samples, each consisting of ten 1-cm-diameter disks, were cut from overwintered infected leaves using a cork-borer whenever leaves were collected for squash mounts. Ascospores were harvested from these leaf samples in a procedure described by Szkolnik (48). Briefly, the disks were wetted with distilled water, attached to the lid of a 9-cm-diameter petri dish filled to a depth of approximately $0.5 \mathrm{~cm}$ with water (10 disks per dish), and inverted over the water for $1 \mathrm{~h}$ at ambient temperature (22 to $26^{\circ} \mathrm{C}$ ). Discharged ascospores quickly settled and adhered to the bottom of the petri dish, allowing the dish to be moved to the stage of a compound microscope. The floor of each petri dish was examined using a $10 \times$ objective $(\times 100$ total magnification), and the ascospores in each of 10 arbitrarily chosen fields of view were enumerated.

Degree-day model. The cumulative percentage of matured ascospores and the $90 \%$ confidence interval around that value were estimated using the degree-day model developed by Gadoury and MacHardy (12). At each site, the date upon which at least $50 \%$ of fruit buds of the apple cultivar McIntosh had reached the green tip stage was selected as the starting date for computation of degree-day accumulations 
(base $\left.=0^{\circ} \mathrm{C}\right)$. A datalogger $($ model CR-10, Campbell Scientific, Inc., Logan, UT) at each site provided hourly records of temperature (model 107, Campbell Scientific), leaf wetness (model 237, Campbell Scientific), and rainfall (model TE525, Campbell Scientific).

Data analysis. Celsius degree-day accumulation (base $=0^{\circ} \mathrm{C}$ ) was used as the independent variable in constructing cumulative distributions of the percentage of ascospores trapped (volumetric spore traps), discharged asci (squash mounts), or ascospores discharged (discharge tests). Because only a single squash mount, discharge test, or volumetric trap assessment was performed on any sampling date at each site, the data obtained by each method were pooled to allow the identification of general trends in slope and variance of the cumulative distributions. The resultant distributions were analyzed by linear regression. Additionally, for each date upon which ascospores were trapped by the volumetric traps, an estimate of ascospore maturity on that date was generated from the degree-day model, and the estimated percentage of mature ascospores was regressed against the observed cumulative percentage of ascospores trapped.

\section{RESULTS}

Squash mounts and discharge tests. Assessments of ascospore discharge generated by examinations of crushed pseudothecia lagged behind the cumulative percentage of ascospores trapped (Fig. 1). At Highland, regression of the cumulative percentage of ascospores collected in the volumetric trap against degree-day accumulation yielded an equation with a significantly greater $(P=0.01)$ slope than a similar analysis in which the percentage of empty asci was regressed against degreeday accumulation (Fig. 1A). The estimated heat unit accumulation associated with 98\% cumulative ascospore trapping was 500 degree days, compared with 850 degree days required to reach $98 \%$ empty asci (Fig. 1A). Using a conservative value of 15 degree days per calendar day based upon examination of long-term weather records (6), the difference in degree-day accumulations required to reach $98 \%$ ascospores trapped versus $98 \%$ empty asci at Highland corresponded to 23 calendar days. Similar disparities between cumulative ascospores trapped and percentages of empty asci were observed at Geneva (Fig. 1B) and Durham (Fig. 1C).

Discharge tests. Cumulative ascospore discharge also lagged behind the cumulative trapping of ascospores under field conditions during 1992 to 1994 at Geneva (Fig. 2) in assessments of leaf samples in laboratory tests. The temporal delay in reaching $98 \%$ ascospore discharge was 420 degree days (Fig. 2), or 28 calendar days assuming a mean temperature of $15^{\circ} \mathrm{C}$ over that period.
Degree-day model of ascospore maturity. Absolute differences between the cumulative percentages of mature ascospores estimated by the degree-day model and those determined by spore trapping were least at the beginning and end of ascospore maturation and greatest during the exponential phase of maturation (Fig. $3 \mathrm{~A})$. The cumulative percentage of ascospores trapped was highly correlated $\left(r^{2}=\right.$ 0.82 ) with predicted ascospore maturity (Fig. 3A), and 154 of the 174 observations $(88.5 \%)$ were contained within the $90 \%$ confidence bands of the degree-day model (Fig. 3B). The observed date upon which $98 \%$ of the ascospores were trapped occurred within 1 to 9 days of the modelcalculated date of $98 \%$ ascospore maturity (Table 1), with a mean difference of 5 days among the 14 site-year combinations of the study.

\section{DISCUSSION}

Practical aspects of using estimates of relative inoculum dose in management of apple scab. The probable severity of infection on any given day is an essential consideration in the efficient deployment of fungicides to manage apple scab. Probable severity of infection has several components: (i) potential ascospore dose (14), i.e., the size and density of the overwintering pathogen population; (ii) target size and susceptibility $(7,9)$; (iii) detection and rating of favorable environmental periods for infection and spread of disease; and (iv) the relative proportion of the pathogen population available for release. The proportion of the season's ascospores available is of greatest consequence when the supply of primary inoculum is exhausted. Except for this salient event, the other components usually override consideration of relative ascospore dose in deployment of fungicides (19). For example, whether 2 or $20 \%$ of the season's ascospores are mature at the green tip stage is a minor concern compared to whether potential ascospore dose in the orchard (14) is 10 or 10,000 ascospores $/ \mathrm{m}^{2}$ of orchard floor. Furthermore, it has been reported in widespread previous studies $(4,10,23,26,30$, $37,44,48-51$ ), and indicated repeatedly in the present study, that mature ascospores are available for release by the green tip stage of apple fruit bud development. Consequently, the need to apply fungicides at the earliest stages of bud development is less dependent upon relative inoculum maturity than upon absolute inoculum dose $(14,34,52)$, target size and susceptibility (7-9), and occurrence of infection periods $(29,33,36)$. Similarly, the impact of an exponential increase in leaf area, as leaves subtending the flower clusters rapidly expand after green tip, far outweighs the influence of two- or threefold variations in the percentage of ascospores matured upon the probable severity of disease $(2,7,8)$. The end result is that the impact of day-today or week-to-week changes in relative inoculum maturity or discharge is minimal compared to the other determinants of disease severity $(2,19)$. Nonetheless, the depletion of the supply of primary inoculum may allow less-intensive use of fungicides once it has been confirmed that primary infections have been successfully controlled. Accuracy in detecting the event is therefore of significance in management of apple scab, and may be more useful than extreme accuracy in estimating relative levels of early-season ascospore development or gauging the exact rate of maturation during the exponential phase of ascospore development.

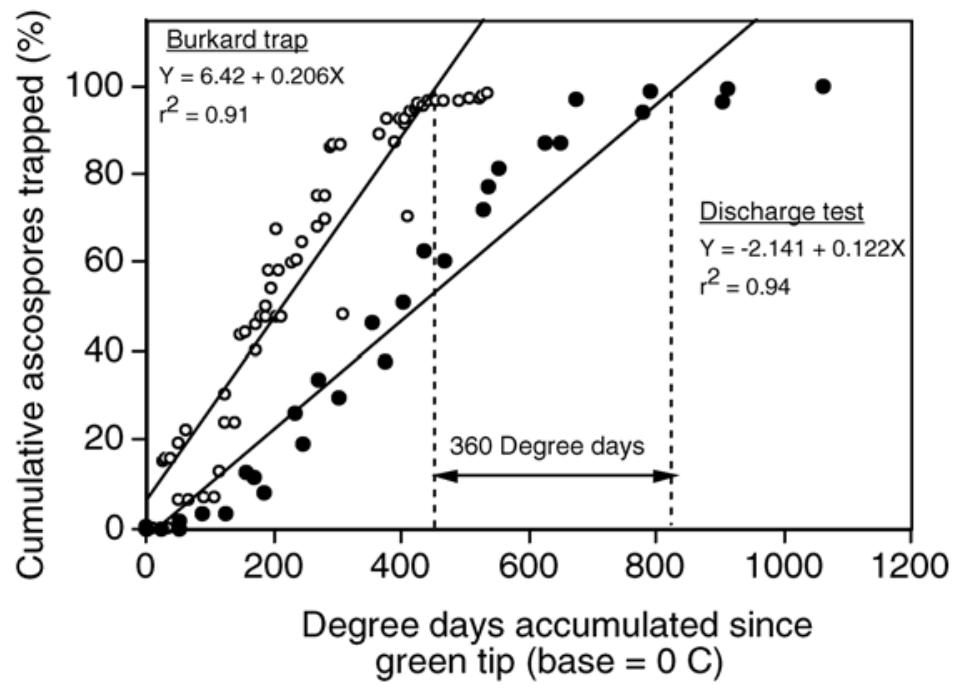

Fig. 2. Cumulative percentage of ascospores of Venturia inaequalis trapped by a Burkard volumetric spore sampler $(\mathrm{O})$ or from laboratory discharge tests $(\bullet)$ of leaves collected from an orchard in $\mathrm{Ge}-$ neva, NY, for the years 1992 to 1994 . Degree-day accumulation (base $=0^{\circ} \mathrm{C}$ ) was calculated from the date of green tip of the apple cultivar McIntosh. Occurrence of $98 \%$ cumulative ascospore release generated by linear regression models fit to the two data sets differed by 360 degree days, which at a mean daily temperature of $15^{\circ} \mathrm{C}$ is equivalent to 24 days. 
Accuracy of the various methods used to assess relative inoculum dose. Our study began with an assumption that airborne inoculum dose as measured by the
Burkard volumetric spore samplers was the standard to which the other measures should be compared. One limitation of comparative studies involving volumetric

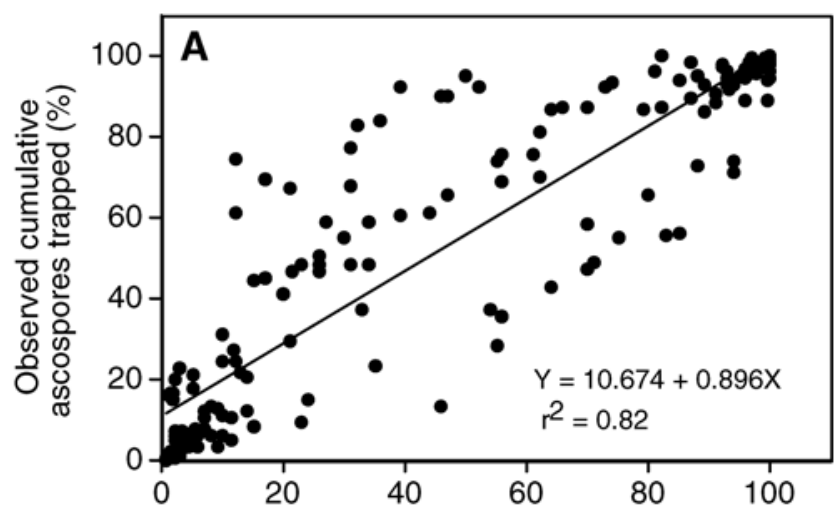

Predicted cumulative ascospore maturity (\%)

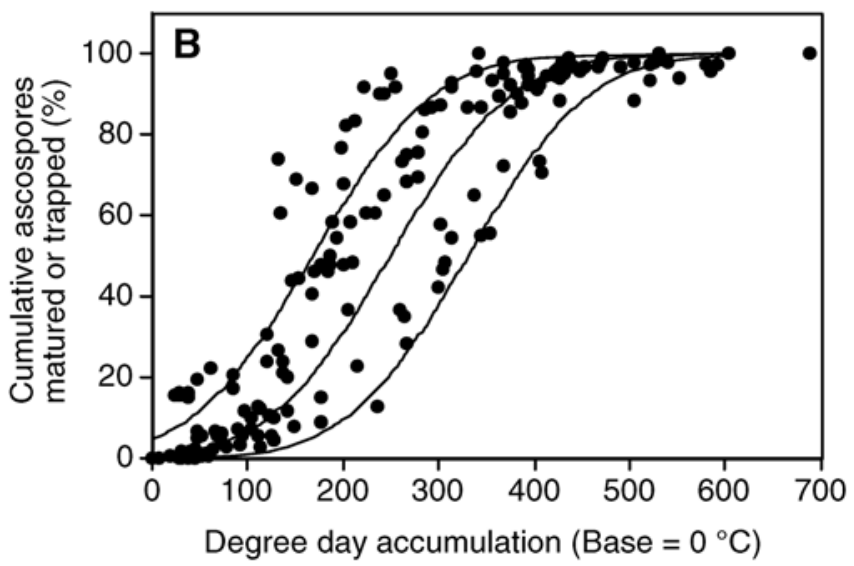

Fig. 3. Relationship between the observed cumulative ascospore release of Venturia inaequalis as measured by a Burkard volumetric spore sampler and cumulative ascospore maturity predicted by a degree-day model for the years 1985 to 1990 in Highland, NY; 1986 to 1990 in Durham, NH; and 1992 to 1994 in Geneva, NY. A, Observed cumulative release versus expected cumulative maturity. B, Observed cumulative release versus degree-day accumulation from the green tip stage of the apple cultivar McIntosh. Central curve represents cumulative maturity predicted by the degree-day model. Outer curves represent the upper and lower $90 \%$ confidence bands of the model for predicted cumulative maturity.

Table 1. Cumulative maturity of Venturia inaequalis ascospores estimated by a degree-day model compared with that observed using Burkard volumetric spore samplers

\begin{tabular}{lccc}
\hline Location & Year & $\begin{array}{c}\text { Date of estimated 98\% } \\
\text { cumulative ascospore } \\
\text { maturity }\end{array}$ & $\begin{array}{c}\text { Date of observed 98\% } \\
\text { cumulative ascospores } \\
\text { trapped }\end{array}$ \\
\hline Durham, NH & 1986 & 25 May & 23 May \\
& 1987 & 22 May & 15 May \\
& 1988 & 26 May & 19 May \\
Highland, NY & 1989 & 31 May & 4 June \\
& 1990 & 24 May & 22 May \\
& 1985 & 15 May & 24 May \\
& 1986 & 9 May & 16 May \\
& 1987 & 9 May & 18 May \\
Geneva, NY & 1988 & 16 May & 17 May \\
& 1989 & 17 May & 23 May \\
& 1990 & 10 May & 4 May \\
& 1992 & 22 May & 26 May \\
& 1993 & 27 May & 31 May \\
& 1994 & 30 May & 1 June \\
\hline
\end{tabular}

a Cumulative maturity was estimated to reach $98 \%$ upon accumulation of 455 degree days (base $=$ $\left.0^{\circ} \mathrm{C}\right)$ starting at the green tip phenophase of the apple cultivar McIntosh.

spore samplers is that the samplers are rarely replicated at a site $(1,25,32,35,39)$ due to cost of the samplers and the quantity of skilled labor required to count the captured spores. Thus, comparisons of squash mounts, discharge tests, or degreeday model forecasts made at a single site and season to a single volumetric trap catch would involve comparisons to a standard of uncertain precision, and with the pretense that volumetric sampler catches were not subject to the normal sources of variation inherent in other forms of measurement. However, by pooling the data from several sites over several seasons, we have been able to identify reproducible differences between various methods of assessment that could not be reliably determined otherwise.

It is also important to note that the various methods do not measure exactly the same response in the pathogen population, and each method has inherent limitations that result in deviations of expected and observed values when results are compared to volumetric trap catches. Methods to assess ascospore maturity and discharge by examination of crushed pseudothecia have been extensively investigated and refined $(11,16,17,48)$. However, this method is possibly the least reliable indicator of when the supply of airborne ascospores has become depleted, and resulted in the greatest disparity between estimated and observed dates of $98 \%$ ascospore discharge. Irrespective of refinements in the method, collection, and removal of a fixed number of pseudothecia from leaf samples cannot correct for attrition in the pathogen population due to decay of leaf litter $(1,14)$, heterogeneity in the discharge mechanism $(21,35)$, or growth of ground cover that may impede escape of ascospores into the orchard air (1). The expected net effect of fixed sampling of a population that is essentially decreasing in size through time would be to shift the distribution forward in time, decrease the slope of the distribution, and delay the estimated date of $98 \%$ ascospore discharge. This is also the disparity that was observed in our study.

Estimates of ascospore depletion based upon discharge from overwintered leaf samples in laboratory assays are subject to the same errors resulting from attrition, and the cumulative distribution generated from these tests exhibited a similar deviation from that measured by volumetric traps in the field. Additionally, this method is sensitive to another source of error. If rain does not occur between two sample collection dates, then cohorts of ascospores may be doubly sampled, and cumulative distributions developed from these data may exhibit distorted and reduced rates of increase (1). Briefly, this error occurs in the following way. Leaf disks used in discharge tests are generally used once and then discarded. Cumulative distributions 
developed from such ascospore discharge tests require an assumption that a cohort of ascospores collected on day 1 is thereby removed from the next sampling date. However, in the absence of rain between collection of leaf samples, there is no discharge, and the total catch in the second sample includes ascospores present on day 1 .

Although the degree-day model was developed to estimate cumulative ascospore maturity, not cumulative ascospore discharge (12), under conditions of frequent rainfall the two parameters can be nearly identical. During the period of our study in Durham, the average time between rain events was 2.4 days. For the period of the study at Geneva and Highland, the average times between rain events were 2.4 and 2.8 days, respectively. Abundant rain, coupled with leaf moisture caused by dew events (12), is the most probable reason why a model of ascospore maturity can so closely approximate ascospore discharge. However, this also indicates that our results should be applied cautiously in more arid geographic areas, or during seasons where extended periods occur without rain. Stensvand et al. $(45,46)$ have improved the fit of the degree-day model to ascospore trapping following dry weather by excluding degree-day accumulation that occurs if rain has not fallen during the previous 4 to 7 days, as have Rossi et al. in Italy (39). Previous studies $(27,28,30,38,42,53)$ have shown that protracted dry weather can delay ascospore maturation in $V$. inaequalis. In the absence of opportunity for ascospore discharge, large deviations between estimated maturity and cumulative ascospore discharge are likely. The degreeday model of ascospore maturity can be used in conjunction with simple rainfall and temperature based rules (19) to model ascospore discharge, and thereby reduce this potential source of error.

The degree-day model of ascospore maturity was developed primarily from sequential discharge tests of screen-encased leaf samples that were incubated under both field and laboratory conditions (12). As such, estimates generated by the model may reflect some of the same artifacts that cause other assessment methods to produce estimates that differ from those of volumetric spore traps in the field. Attrition of the airborne population due to leaf litter decay $(1,14)$, sporadic release $(21,35)$, or interception of ascospores by groundcover (1) would create a cumulative distribution of airborne spores that was both shifted earlier in time and with a greater slope than that of the degree-day model, both of which may have been indicated when we regressed observed cumulative airborne dose against estimated ascospore maturity (Fig. 3). Aylor has described corrections for some of the above sources of attrition (1), and these might be modified and applied to the degree-day model. Alternatively, careful selection of release events to include only those where all the available ascospores were released might allow the eventual formulation of a new degree-day model based upon airborne spore trapping. Such a model might better reflect attrition in the airborne ascospore population, and is one focus of our current research.

In conclusion, estimates of cumulative ascospore maturity generated by the degree-day model, as presently formulated, appear to be more closely related to actual airborne ascospore dose than do estimates obtained by either squash mounts or discharge tests. Furthermore, the degree-day model could be used to more accurately detect the date of $98 \%$ cumulative ascospore trapping. The degree-day model can easily be applied to any site for which temperature data can be obtained, and can be used in conjunction with geographic information systems and high-resolution weather forecasts (43) to generate multisite and regional estimates of ascospore maturity and release. Where such information on pathogen development is currently needed for management of apple scab, but is unavailable due to the limited scope or availability of direct assessments, the degreeday model may supply information that is timely and sufficiently accurate for use in advisory programs. Indeed, our results indicate that information provided by the degree-day model would most often be more accurate than direct assessments, although additional validation studies may be desirable in drier climates before the degree-day model is adopted.

\section{LITERATURE CITED}

1. Aylor, D. E. 1996. Comparison of the seasonal pattern of airborne Venturia inaequalis ascospores with the release potential of $V$. inaequalis ascospores from a source. Phytopathology 86:769-776.

2. Aylor, D. E. 1998. The aerobiology of apple scab. Plant Dis. 82:838-849.

3. Brook, P. J. 1966. The ascospore production season of Venturia inaequalis (Cke.) Wint., the apple black spot fungus. N.Z. J. Agric. Res. 9:1064-1069.

4. Brook, P. J. 1976. Seasonal pattern of maturation of Venturia inaequalis ascospores in New Zealand. N.Z. J. Agric. Res. 19:103-109.

5. Childs, L. 1917. New facts regarding the period of ascospore discharge of the apple scab fungus. Oreg. Agric. Exp. Stn. Bull. No. 143.

6. Dethier, B. E., and Vittum, M. T. 1967. Growing degree days in New York State. N.Y. Agric. Exp. Stn. Bull. 1017.

7. Falk, S. P., Gadoury, D. M., and Seem, R. C. 1995. Analysis of risk of primary apple scab infection. (Abstr.) Phytopathology 85:1556.

8. Falk, S. P., Gadoury, D. M., and Seem, R. C. 1996. Impact of ontogenic resistance and fenarimol on seasonal development of scab on apple foliage. (Abstr.) Phytopathology 86:S8586.

9. Ficke, A., Gadoury, D. M., and Seem, R. C. 2002. Ontogenic resistance and plant disease management: A case study of grape powdery mildew. Phytopathology 92:671-675.

10. Frey, C. N., and Keitt, G. W. 1925. Studies of spore dissemination of Venturia inaequalis (Cke.) Wint. in relation to seasonal development of apple scab. J. Agric. Res. 15:529-540.
11. Gadoury, D. M., and MacHardy, W. E. 1982. Preparation and interpretation of squash mounts of pseudothecia of Venturia inaequalis. Phytopathology 72:92-95

12. Gadoury, D. M., and MacHardy, W. E. 1982. A model to estimate the maturity of ascospores of Venturia inaequalis. Phytopathology 72:901-904.

13. Gadoury, D. M., and MacHardy, W. E. 1983. A 7-day recording volumentric spore trap. Phytopathology 73:1526-1531.

14. Gadoury, D. M., and MacHardy, W. E. 1986. Forecasting ascospore dose of Venturia inaequalis in commercial apple orchards. Phytopathology 76:112-118.

15. Gadoury, D. M., MacHardy, W. E., and Rosenberger, D. A. 1989. Integration of pesticide application schedules for disease and insect control in apple orchards of the northeastern United States. Plant Dis. 73:98-105.

16. Gadoury, D. M., Rosenberger, D. A., Barnard, J., and MacHardy, W. E. 1992. Variation and error in estimates of ascospore maturity and discharge derived from examination of crushed pseudothecia of Venturia inaequalis. Plant Dis. 76:717-720.

17. Gadoury, D. M., Seem, R. C., Rosenberger, D. A., Wilcox, W. F., MacHardy, W. E., and Berkette, L. P. 1992. Disparity between morphological maturity of ascospores and physiological maturity of asci in Venturia inaequalis. Plant Dis. 76:277-282.

18. Gadoury, D. M., Seem, R. C., and Stensvand, A. 1994. Ascospore discharge in Venturia inaequalis. Norw. J. Agric. Sci. Suppl. 17:205219.

19. Gadoury, D. M., Seem, R. C., and Stensvand, A. 1995. New developments in forecasting the risk of apple scab. N.Y. Fruit Q. 2:5-8.

20. Gadoury, D. M., Stensvand, A., and Seem, R. C. 1996. A wind tunnel for controlledenvironment studies of ascospore release by Venturia inaequalis. Phytopathology 86:596601.

21. Gadoury, D. M., Stensvand, A., and Seem, R C. 1998. Influence of light, relative humidity, and maturity of populations on discharge of ascospores of Venturia inaequalis. Phytopathology 88:902-909.

22. Gilpatrick, J. D., Smith, C. A., and Blowers, D. R. 1972. A method of collecting ascospores of Venturia inaequalis for spore germination studies. Plant Dis. Rep. 56:39-42.

23. Gilpatrick, J. D., and Szkolnik, M. 1976. Maturation and discharge of ascospores of the apple scab fungus. Proc. Apple Pear Scab Workshop. N.Y. Agric. Exp. Stn. Bull. Spec. Rep. 28:1-6.

24. Gjærum, H. B. 1954. Ascospore maturity, dissemination and infection by apple scab. Norw. Plant Prot. Inst. Bull. No. 13.

25. Hirst, J. M., and Stedman, O. J. 1962. The epidemiology of apple scab (Venturia inaequalis (Cke.) Wint.) II. Observations on the liberation of ascospores. Ann. Appl. Biol. 50:525-550

26. Hirst, J. M., Storey, I. F., Ward, W. C., and Wilcox, H. J. 1955. The origin of apple scab epidemics in the Wisbech area in 1953 and 1954. Plant Pathol. 4:91-96.

27. James, J. R., and Sutton, T. B. 1982. Environmental factors influencing pseudothecial development and ascospore maturation of Venturia inaequalis. Phytopathology 72:10731080.

28. James, J. R., and Sutton, T. B. 1982. A model for predicting ascospore maturation of Venturia inaequalis. Phytopathology 72:10811085.

29. Jones, A. L., and Aldwinckle, H. S. 1990. Compendium of Apple and Pear Diseases. American Phytopathological Society, St. Paul, MN.

30. Keitt, G. W., and Jones, L. K. 1926. Studies of 
the epidemiology and control of apple scab. Wis. Agric. Exp. Stn. Res. Bull. 73.

31. MacHardy, W. E., and Gadoury, D. M. 1985. Forecasting the seasonal maturation of ascospores of Venturia inaequalis. Phytopathology 75:381-385.

32. MacHardy, W. E., and Gadoury, D. M. 1986. Patterns of ascospore discharge by Venturia inaequalis. Phytopathology 76:985-990.

33. MacHardy, W. E., and Gadoury, D. M. 1989. A revision of Mills's criteria for predicting apple scab infection periods. Phytopathology 79:304-310.

34. MacHardy, W. E., Gadoury, D. M., and Rosenberger, D. A. 1993. Delaying the onset of fungicide programs for control of apple scab in orchards with low potential ascospore dose of Venturia inaequalis. Plant Dis. 77:372-375.

35. Miller, P. M., and Waggoner, P. E. 1958. Dissemination of Venturia inaequalis ascospores. Phytopathology 48:416-419.

36. Mills, W. D. 1944. Efficient use of sulfur dusts and sprays during rain to control apple scab. Cornell Ext. Bull. 630

37. Norin, I. 1989. Skorvvarning - erfarenheter av 1988 års fors $\emptyset \mathrm{k}$. Frukt- och Bärodling 1(1989):42-45.

38. O'Leary, A. L., and Sutton, T. B. 1986. The influence of temperature and moisture on the quantitative production of pseudothecia of Venturia inaequalis. Phytopathology 76:199-204.
39. Rossi, V., Ponti, I., Marinelli, M., Giosue, S., and Bugiani, R. 1999. Field evaluation of some models estimating the seasonal pattern of airborne ascospores of Venturia inaequalis. J. Phytopathol. 147:567-575.

40. St-Arnaud, M., and Neumann, P. 1990. Évaluation au Québec d'un modèle de la prédiction de la fin de la période annuelle d'éjection des ascospores du Venturia inaequalis. Phytoprotection 71:17-23.

41. Schneiderhan, F. J. 1925. Rainfall in relation to ascospore discharge and infection in Venturia inaequalis. Phytopathology 15:56.

42. Schwabe, W. F. S., Jones, A. L., and van Blerk, E. 1989. Relation of degree-day accumulations to maturation of ascospores of Venturia inaequalis in South Africa. Phytophylactica 21:13-16.

43. Seem, R. C., Magarey, R. D., Zack, J. W., and Russo, J. M. 2000. Estimating disease risk at the whole plant level with general circulation models. Environ. Poll. 108:389-395.

44. Stensvand, A., Amundsen, T., and Semb, L. 1994. Apple scab (Venturia inaequalis) - patterns of ascospore release in Norway. Norw. J. Agric. Sci.. Suppl. 17:49-54.

45. Stensvand, A., Gadoury, D. M., Amundsen, T., and Seem, R. C. 2000. Recent research on ascospore discharge in Venturia inaequalis. IOBC Bull. 23:39-51

46. Stensvand, A., Gadoury, D. M., Seem, R. C.,
Amundsen, T., and Falk, S. P. 1998. Some recent advances in epidemiology of apple scab. Proc. ICPP 3:50.

47. Stover, W. G., and Johnson, H. W. 1924. First progress report on the study of apple scab un der Ohio conditions. Phytopathology 14:60.

48. Szkolnik, M. 1969. Maturation and discharge of ascospores of Venturia inaequalis. Plan Dis. Rep. 53:534-537.

49. Szkolnik, M. 1974. Apple scab ascospore release as related to apple fruit bud development and calendar dates. Proc. Am. Phytopathol. Soc. 1:146.

50. Weber, A. 1935. Undersøgelser over æbleskurvens (Venturia inaequalis) overvintring. Tidsskr. Planteavl 40:754-758.

51. Wiesman, R. 1935. Untersuchungen über die Bedeutung der Ascosporen (Wintersporen) und die Konidien and den schorfigen Trieben für die entstehung der Primärinfektionen des Apfelschorfpilzes Fusicladium dendriticum. Separatabdruck aus dem Landwirtschaftlichen Jahrbuch der Schweiz 1935.

52. Wilcox, W. F., Wasson, D. I., and Kovach, J. 1992. Development and evaluation of an integrated, reduced-spray program for control of apple scab in New York. Plant Dis. 76:669 677.

53. Wilson, E. E. 1928. Studies of the development of the ascigerous stage of Venturia in aequalis. Phytopathology 18:375-420. 